\title{
Feasibility of Breast Conserving Surgery in locally Advanced Breast Cancer Patients Treated with Neoaduvant Therapy
}

\author{
Awad Ali M Alawad* \\ Faculty of Medicine, University of Medical Sciences and Technology, Sudan \\ Submission: January 30, 2017; Published: January 31, 2017 \\ *Corresponding author: Awad Ali M Alawad, Department of Surgery, University of Medical Sciences and Technology, Sudan, \\ Email: awadali82@hotmail.com
}

\section{Editorial}

For a long time, breast-conserving surgery has been a subject of great interest and debate. Many researchers have tried to find strict criteria in selecting the patients who can benefit from such a treatment but this remains a goal to achieve in the future. Locally advanced breast cancer (LABC) presents a challenge to surgeons. The standard treatment of locally advanced breast cancer is neoadjuvant chemotherapy (NACT). It has a high rate of success, causing complete clinical response in some patients and down staging the tumor in many patients. Patients with LABC previously treated by modified radical mastectomy could now be offered the chance for breast conserving surgery. Several studies have documented the feasibility and safety of breast conservation for locally advanced breast cancer after preoperative chemotherapy [1,2]. Breast conservation is possible in $27 \%$ to $90 \%$ of patients after preoperative chemotherapy. Local recurrence rates after breast conservation are low (5\% $10 \%$ ) in patients who respond to preoperative chemotherapy [3].

A common question raised with respect to performing breast-conserving therapy after neoadjuvant chemotherapy is the volume of breast tissue that should be resected. To evaluate this, Boughey et al. studied [4] whether preoperative chemotherapy was able to reduce the volume of tissue excised and the number of breast operations performed and reported that in patients with T2 or T3 tumors, significantly less tissue was resected when patients received neoadjuvant chemotherapy ( $\mathrm{P}<.004$ for volume of tissue resected). At a median followup time of 33 months there were only two cases of ipsilateral breast recurrence, one in the neoadjuvant group, and one in the adjuvant group, leading them to conclude that it is not necessary to excise the entire pre NACT volume of tissue. Therefore, using chemotherapy in the preoperative setting can afford a better overall cosmetic outcome for patients.

Finally, sufficient evidence is now available to suggest that breast conservation after neoadjuvant chemotherapy is safe and effective for properly selected patients. Neoadjuvant chemotherapy may permit a breast conservation approach for selected patients with initial tumor sizes that require mastectomy and it does not compromise excellent outcome for patients with early stage disease. Neoadjuvant chemotherapy does increase the complexity of breast conservative treatment and requires a close collaboration between a multidisciplinary team to achieve excellent outcomes.

\section{References}

1. Ahmed AA (2014) Clinicopathological profile of female Sudanese patients with locally advanced breast cancer. Breast Dis 34(3): 131134.

2. Alawad AA (2014) Evaluation of clinical and pathological response after two cycles of neoadjuvant chemotherapy on Sudanese patients with locally advanced breast cancer. Ethiop J Health Sci 24(1): 15-20.

3. Gismalla MA, Alawad AA (2014) Factors associated with local recurrence after mastectomy for invasive breast cancer in sudanese patients. International Research on Medical Sciences 2(2): 026-30.

4. Alawad AAM (2015) Management of Inflammatory breast cancer: current concepts. Int J Case Rep Images 6(7): 460-461. 
CC This work is licensed under Creative BY Commons Attribution 4.0 Licens
Your next submission with Juniper Publishers will reach you the below assets

- Quality Editorial service

- Swift Peer Review

- Reprints availability

- E-prints Service

- Manuscript Podcast for convenient understanding

- Global attainment for your research

- Manuscript accessibility in different formats

( Pdf, E-pub, Full Text, Audio)

- Unceasing customer service

Track the below URL for one-step submission https://juniperpublishers.com/online-submission.php 